\title{
Short- and Long-term Outcomes After Curative Surgery for Rectal Cancer in Patients Under the Age of Fourty Years: A Stage Based Case-match Analysis
}

\author{
Kırk Yaş Altı Rektum Kanseri Olgularında Küratif Cerrahi Sonrası Kısa ve Uzun Dönem \\ Sonuçlar: Evre Bazında Olgu Eșleștirme Analizi
}

(D) Osman Civil, (D) Mustafa Öncel

2istanbul Medipol University Faculty of Medicine, Department of General Surgery, İstanbul, Turkey

\begin{abstract}
Introduction: The aim of the study is to compare the short and long-term outcomes after curative surgery for rectal cancer in patients under the age of 40 years and over the age of 50 years. Methods: A total of 46 patients with rectal cancer were retrieved from a prospectively designed database after the exclusion of stage 4 cases ( $<40$ group). A case-match group (1:2) at similar stage was created among patients over 50 years of age $>50$ group, $n=92$ ). Demographics, perioperative information, and oncological and pathological results were compared between the groups. The primary outcome measure was 5 year survival. Results: The numbers of male cases were similar ( $59 \%$ vs $52 \%$, $p=0.468$ ) between the groups. There were more patients who received preoperative radiation $(98 \%$ vs $71 \%, p<0.001)$ in $<40$ group related to the location of the tumor and intolerance to the treatment. The tumors were closer to the dentate line $[3(0-15) \mathrm{cm}$ vs $5(0-15) \mathrm{cm}, \mathrm{p}=0.006)]$ and the rate of abdominoperineal resection was higher (39\% vs $22 \%, p=0.031$ ) in $<40$ group. Laparoscopy ( $72 \%$ vs $85 \%, p=0.069)$, conversion to open surgery ( $7 \%$ vs $10 \%), p=0.751)$, operation time ( $224 \pm 57$ $\min$ vs $210 \pm 62 \mathrm{~min}, p=0.226)$, intraoperative bleeding [200 (10-1300) mL vs $200(10-1500) \mathrm{mL}, p=0.514]$, requirement of perioperative transfusion ( $30 \%$ vs $27 \%, p=0.688$ ), reoperation ( $2 \%$ vs $2 \%, p=0.999)$ and 30 day mortality ( $2 \%$ vs $1 \%, p=0.333)$ rates, hospitalization period [7 (4-49) vs 7 (2-47) days, $p=0.25$ ] were similar. Tumor differentiation was poorer $(p=0.046)$ in $<40$ group, but other pathological parameters were similar between the groups: number of harvested lymph nodes [14 (0-53) vs 12 (0-43), $p=0172]$, number of malignant lymph nodes $[1(0-29)$ vs $1(0-11), p=0.616]$ and invasion rates $[(0.09$ $0-0.93)$ vs $0.07(0-0.82), \quad p=0.762]$. Kaplan-Meier analysis revealed similar 5 year survival rates ( $63 \%$ vs $60 \%, p=0.052$ ). Conclusion: When similar tumor stages are considered, the survival is similar in rectal cancer patients below the age of 40 years and over the age of 50 years.
\end{abstract}

$\ddot{0} Z$

Amaç: Kırk yaş altı rektum kanseri olan hastalarda küratif cerrahi sonrası kısa ve uzun dönem sonuçları 50 yaș üzeri hastalar ile karşılaștırmaktır.

Yöntemler: Prospektif olarak tutulan veritabanından evre 4 hastalar dışlandıktan sonra 40 yaș altı (<40 grup) rektum kanseri olan hastalar ile 50 yaş üzeri ( $>50$ grup) rektum kanserli hastalar 1:2 oranında patolojik evre bazında olgu-eșleștirme yöntemiyle demografik veriler, perioperatif veriler, onkolojik ve patolojik sonuçlar açısından karșılaștırıldı. Birincil sonlanım noktası beș yıllık sağkalım idi. Bulgular: Gruplar arasında cinsiyet dağılımı benzerdi (\%59 vs $\% 52$ erkek, $p=0,468)$. <40 grupta daha yüksek oranda (\%98 vs \%71, $\mathrm{p}<0,001)$ neoadjuvan radyoterapi uygulanmıștı. $<40$ grubunda tümör dentate çizgiye daha yakın olup [3 (0$15 \mathrm{~cm}$ vs $5(0-15) \mathrm{cm}, \mathrm{p}=0,006]$ abdominoperineal rezeksiyon daha yüksek orandaydı (\%39 vs $\% 22, p=0,031)$. Laparoskopik operasyon (\%72 vs \%85, $p=0,069)$, açı̆̆a geçiș (\%7 vs \%10), $p=0.751)$, operasyon süresi ( $224 \pm 57 \mathrm{dk}$ vs $210 \pm 62 \mathrm{dk}, \mathrm{p}=0,226)$, kanama [200 (10-1300) mL vs 200 (10-1500) mL, p=0,514], kan transfüzyonu (\%30 vs $\% 27, p=0,688$ ), reoperasyon ( $\% 2$ vs $\% 2$, $p=0,999)$ ve 30 günlük mortalite ( $\% 2$ vs $\% 1, p=0,333)$ oranları ile hastanede kalış süreleri [7 (4-49) vs 7 (2-47) gün, $p=0,25]$ benzerdi. Tümör diferansiyasyonu $<40$ grupta daha kötü olup $(p=0,046)$ diğer patolojik parametreler benzerdi: çıkarılan lenf nodu [14 (0-53 vs $12(0-43), p=0,172]$, malign lenf nodu [ 1 (0$29)$ vs $1(0-11), p=0,616]$ ve invazyon oranları $[0.09(0-0,93)$ vs $0,07(0-0,82), p=0,762]$. Kaplan-Meier analizi benzer oranda beș yıllık sağkalım oranları (\%63 vs \%60, $p=0,052$ ) gösterdi. Sonuç: Benzer tümör evreleri değerlendirildiğinden 40 yaș altı ve 50 yaş üzeri rektum kanseri olgularında sağkalım benzerdir. Anahtar Kelimeler: Rektum kanseri,gençhasta, sağkalım, sonuç

Keywords: Rectal cancer, young, survival, outcome 


\section{Introduction}

Rectum is one of the most common locations for adenocarcinoma, and colorectal cancer (CRC) continues to present among the leading tumors in Western World and developing countries, causing mortality (1). Recent studies have revealed a significant increase in the incidence of CRC in young population occurring over the past two decades (2-4). A recent report from United States nationwide Surveillance, Epidemiology and End Results cancer registry has indicated an annual increment of 2.6\% in rectal carcinoma at younger ages (5).

The nature of CRC at younger ages may reveal several differences. Some have advocated that CRC at younger ages may have an aggressive histopathology and is diagnosed at more advanced stages (6). Several studies have shown that the rate of mucinous and signet-ring cell adenocarcinomas is higher in younger cases with $\operatorname{CRC}(7,8)$. Besides, there is conflicting information about survival with some studies suggesting a worse prognosis for young patients while other studies show no differences in long-term cancer outcomes among young and older cases with CRC $(5,7,9,10)$. These contradictory reports may be related to the nature of the disease since younger people may have a more aggressive tumor behavior (9). Thus, current study aims to compare the short- and long-term outcomes of surgery in young $(<40)$ and old $(>50)$ patients in a case-match design considering the stages of the cancer.

\section{Methods}

All consecutive patients under the age of 40 years, operated for rectal cancer at Kartal Training and Research Hospital between 2003 and 2012 and Department of Oncological and Colorectal Surgery at Medipol University between 2012 and 2018, were retrospectively retrieved from our prospectively maintained database. A senior surgeon (MÖ) operated or supervised all procedures. Prior to the initiation of the data retrieval, the local ethics committee approved the content of the study (10840098-604.01.01-E21586). Because, there were no direct interactions with subjects and knowledge gained would not impact subject's clinical care, informed consent was not obtained. Patients with stage four tumors were excluded from further analyses, and a total of 46 cases under the age of 40 years were identified as the study group (group <40). A case-match analysis was completed with patients over 50 -year-old from the same database for the creation of the comparison group (group $>50$ ) considering similar stage distribution between the groups and in a 1:2 ratio $(n=92)$. Patients who were operated for benign conditions or premalignant lesions including in situ carcinomas, those receiving a palliative procedure (such as a diverting colostomy or exploration of the abdominal cavity because of carcinomatosis) or those having an emergent resection were excluded from the study. If the intended laparoscopic steps were not completed laparoscopically and necessitated any unplanned incision or the extension of a previously made incision to allow direct visualization for continued dissection, they were defined as conversion.

These outcome measures were compared between $<40$ and $>50$ groups: demographics, concomitant diseases (hypertension, diabetes mellitus
(DM), chronic lung disease, chronic obstructive pulmonary disease, cerebrovascular accident, chronic liver disease, chronic renal failure, previous malignancy), American Society of Anesthesia (ASA) scores, tumor location (distance from the dentate line), neoadjuvant radiation therapy, operation technique (laparoscopic, conventional), conversion rate and causes, operation type (abdominoperineal resection, low anterior resection), anastomotic technique (stapled, handsewn), additional organ resection, operation time, intraoperative bleeding, rate and amount of perioperative blood transfusion, complications, reoperations, length of stay, 30-day mortality, pathological results [differentiation, $\mathrm{T}$ and $\mathrm{N}$ stages (and number of tumor positive lymph nodes), number of harvested lymph nodes, vascular and perineural invasion, and survival. The primary outcome measure was 5-year survival].

\section{Statistical Analysis}

Data were analyzed by using SPSS 21.0 for Windows (Armonk, NY, IBM Corp). Results were given as percentages, mean with standard deviations or median and ranges. Quantitative and qualitative variables were compared with Student's t-test, Mann-Whitney U test and chi-square (Pearson's or Fischer's Exact) tests, respectively. Kaplan-Meier analysis was used for survival analysis. A p value less than 0.05 was considered to be significant.

\section{Results}

There were 46 and 92 patients and the median (range) ages were 35.5 (24-40) and 63 (51-87) years in $<40$ and $>50$ groups, respectively. The number of male cases was similar. American Society of Anesthesiology score was higher and the number of patients with a concomitant disease was more in $>50$ group: hypertension [1 (2.2\%) vs 34 (37\%), $p<0.001]$, DM [2 (4.3\%) vs 19 (20.7\%), $p=0.012$, chronic lung disease [0 vs 7 (7.6\%), $p=0.095$ ], chronic obstructive pulmonary disease [0 vs 7 (7.6\%), $p=0.095$, cerebrovascular accident [0 vs $3(3.3 \%), p=0.551]$, previous malignancy [0 vs 3 (3.3\%), $p=0.551$ ] chronic renal failure [0 vs $2(2.2 \%)$, $\mathrm{p}=0.552]$ and chronic liver disease $[1(2.2 \%)$ vs $0, p=0.333$ ], in groups $<40$ and $>50$, respectively. The tumors were closer to the dentate line and there were more patients who received preoperative radiation in $<40$ group related to the location of the tumor and intolerance to the treatment (Table 1).

Most of the patients were laparoscopically operated and conversion rates were less than $10 \%$ and similar between the groups (Table 2 ). The causes for conversion were T4 tumor $(n=2)$ and bleeding $(n=1)$ in $<40$ group and T4 tumor $(n=5)$, bowel perforation $(n=1)$, severe adhesions $(n=1)$ and difficulty in creation of the anastomosis $(n=1)$ in $>50$ group. A total of 29 cases required additional organ resection: vagina $(n=5)$, bladder $(n=2)$, uterus $(n=1)$, and ovary $(n=1)$ in $<40$ group and vagina $(n=11)$, bladder $(n=7)$, ovary $(n=4)$, ureter $(n=3)$, uterus $(n=3)$, prostate $(n=3)$ and small bowel $(n=1)$ in $>50$ group. The rate of sphinctersaving procedure was more in $>50$ group. There were three patients necessitated a re-operation; one in $<40$ group for bowel obstruction and 2 in $>50$ group for stoma prolapse or anastomotic leak. Two patients 
(one in each group) died during the postoperative period because of pulmonary embolism or intraabdominal sepsis secondary to an anastomotic leak. Other perioperative measures, length of stay, and rates of complications, reoperation and 30-day mortality were similar between the groups (Table 2). Tumor differentiation was significantly poorer in $<40$ group, but other pathological parameters were similar between the groups (Table 3). Kaplan-Meier analysis revealed similar 5-year survival rates (Figure 1).

Table 1. Demographics, patient-related information, tumor location and preoperative radiotherapy

\begin{tabular}{|l|l|l|l|}
\hline & Group $<\mathbf{4 0}$ & Group $>\mathbf{5 0}$ & $\mathbf{p}$ \\
\hline Gender (male) (\%) & $27(58.7)$ & $48(52.2)$ & 0.468 \\
\hline ASA score (\%) & - & - & $<0.001$ \\
\hline 1 & $20(43.5)$ & $5(5.4)$ & - \\
\hline 2 & $19(41.3)$ & $52(56.5)$ & - \\
\hline 4 & $7(15.2)$ & $34(37)$ & - \\
\hline Concomitant Diseases (\%) & 0 & $1(1.1)$ & - \\
\hline Tumor location* [median (range)] & $4(8.7)$ & $50(54.3)$ & $<0.001$ \\
\hline Preoperative radiotherapy (\%) & $3(0-15)$ & $5(0-15)$ & $<0.001$ \\
\hline ASA: American Society of Anesthesia, *distance from the dentate line & $45(97.8)$ & $65(70.7)$ & $<0.001$ \\
\hline
\end{tabular}

Table 2. Perioperative measures including intra-operative information, complications and post-operative outcomes

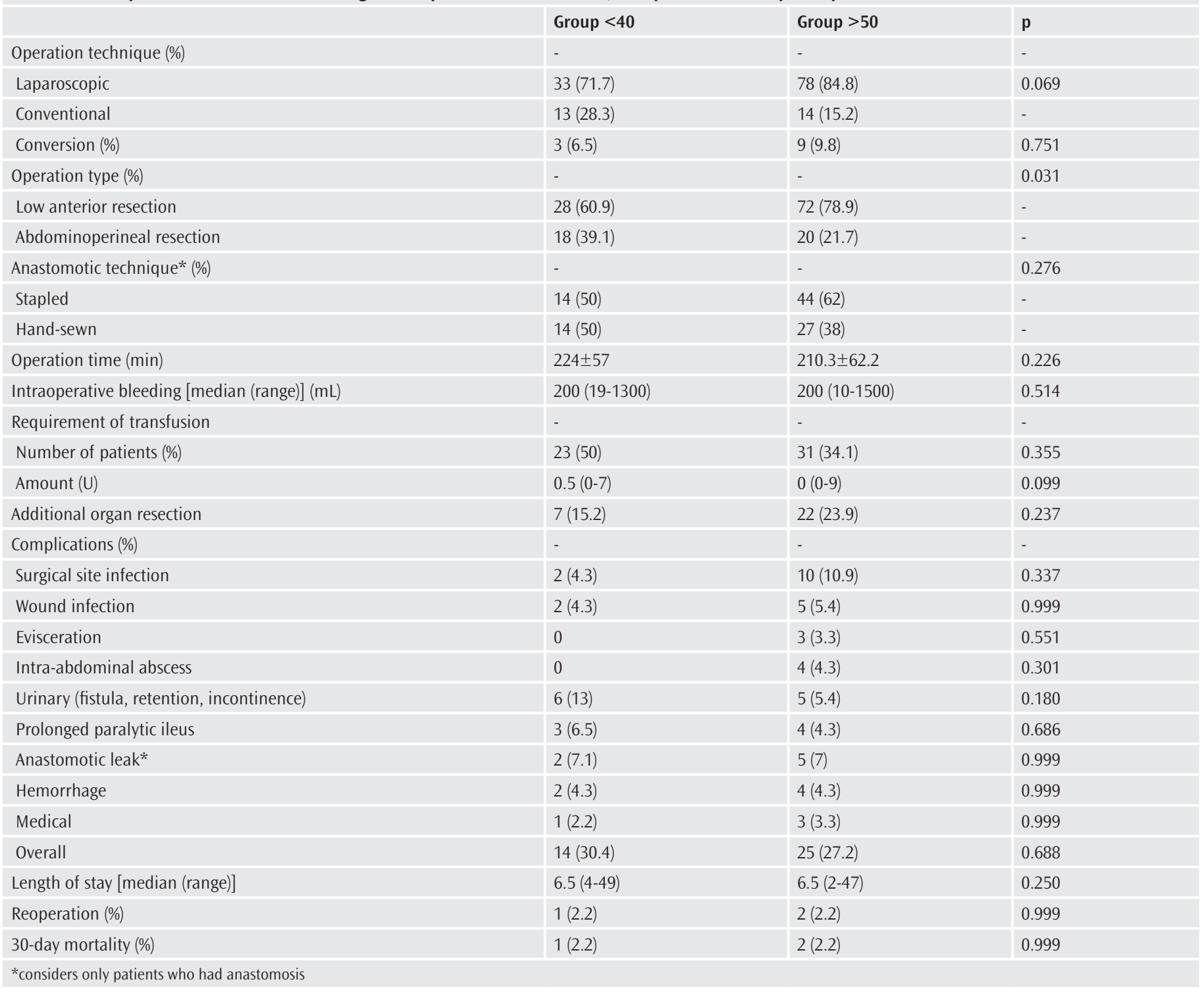


Table 3. Pathological outcomes

\begin{tabular}{|c|c|c|c|}
\hline & Group $<40$ & Group $>50$ & $\mathbf{p}$ \\
\hline 0 & $6(13)$ & $12(13)$ & - \\
\hline 2 & $5(10.9)$ & $6(6.5)$ & - \\
\hline 3 & $30(65.2)$ & $60(65.2)$ & - \\
\hline ypN stage (\%) & - & - & 0.787 \\
\hline 0 & $20(43.5)$ & $38(42.2)$ & - \\
\hline 1 & $16(34.8)$ & $36(40)$ & - \\
\hline 2 & $10(21.7)$ & $16(17.8)$ & - \\
\hline 2 & $10(21.7)$ & $20(21.7)$ & - \\
\hline 3 & $25(54.3)$ & $50(54.3)$ & - \\
\hline Differentiation (\%) & - & - & 0.046 \\
\hline Poor & $8(17.4)$ & $5(5.4)$ & - \\
\hline Moderate & $17(37)$ & $51(55.4)$ & - \\
\hline Well & $12(26.1)$ & $16(17.4)$ & - \\
\hline Unknown & $9(19.6)$ & $20(21.7)$ & - \\
\hline Lymphovascular invasion (\%) & $14(32.6)$ & $28(34.6)$ & 0.822 \\
\hline
\end{tabular}

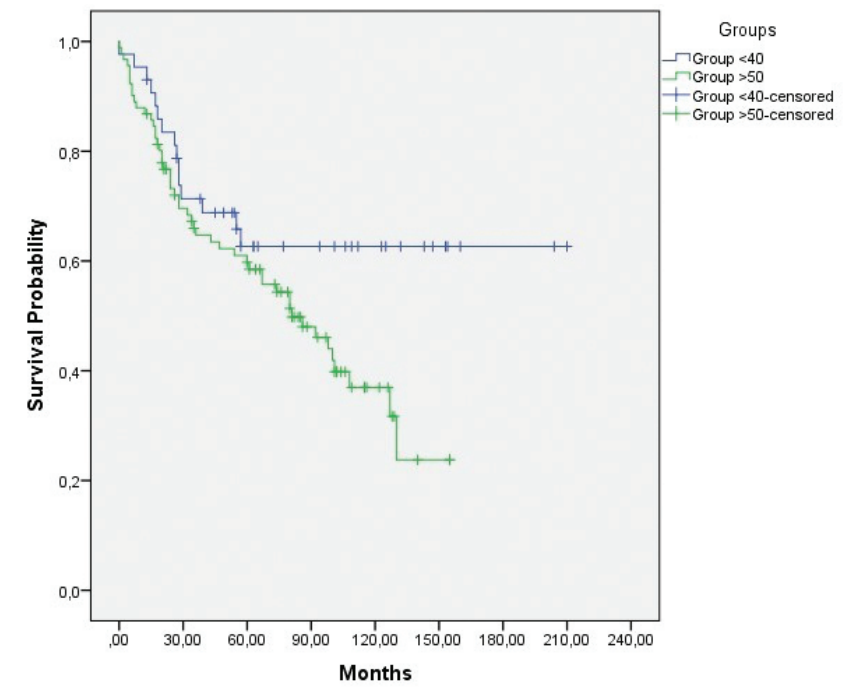

Figure 1. The 5 -year survival rates after surgery were similar between the groups $(62.7 \%$ and $59.8 \%$ in $<40$ and $>50$ groups, respectively, $p=0.052$ )

\section{Discussion}

Current study evaluates the outcomes of curative surgery in rectal cancer patients younger than 40 years old. It is a comparative evaluation and the comparison group is composed of those older than 50 years old. In order to strength the homogeneity, the case-match of the comparison group is completed considering the stage of the tumor, since rectal cancer tends to be at more advanced stage at the time of diagnosis in younger population (8). In addition, a single surgeon has operated or supervised surgery in all patients in both groups; thus, surgeon has a minor impact on the results and conclusions of this study.

The patient and disease related measures are comparable between the groups. As expected, male gender rate is slightly higher in both groups, but the comparison between the groups does not reveal significance. Perioperative and pathological measures including operation time, intraoperative bleeding, requirement of transfusion, number of harvested lymph nodes are comparable between the groups. These findings make the conclusions of the postoperative outcomes and oncological measures more reliable. Besides -as expected- the rate of 
having a concomitant disease and consequently ASA score is higher in $>50$ group. It is an interesting finding that patients' general condition and having additional diseases have not an impact on early postoperative results particularly on complication rates (data not shown). Thus, current study reveals that the postoperative complication profile may be similar in young and older patients.

Current study gives information about the nature of the rectal carcinoma in young population although the number of the patients and the casematch design of the study limit the conclusions. The number of T4 tumors and additional organ resections and the rate of preoperative radiotherapy show that the rate of advanced disease is probably higher in the studied population. In a recent study from SEER data has also revealed that the stage of the rectal cancer is more advanced in younger group between the ages of 20 and 39 years than in older patients over 40 years of age (8). The actual reason for this characteristic is not known but may be related to the screening programs that begins at the age of 50 years or to the behavior of the tumor at younger age. The higher incidence of more aggressive histological subtypes may also have a genetic basis (1). Other pathological measures have driven forward that the nature of the tumor may be different in younger population, since several parameters linked to poor pathological features are more common in younger CRC patients. These include poor differentiation, and mucinous and signet-ring cell histology $(7,8,11)$. Current data support this information since poorly differentiated cancer rate is significantly higher in $<40$ group.

Several studies have advocated that the anatomic distribution of the tumor is moving to the rectum at younger ages $(2,7,8)$. Two recent nationwide analyses have shown an increase in rectal cancer in patients under 40 years of age, while the incidence of colon cancer appears stable $(8,12)$. Besides that, the location of rectal cancer (i.e. low, mid or upper) is extremely significant in routine practice since it is linked to the possibility of the sphincter preservation. However, whether or not the location of the rectal cancer and the operation type vary in younger population is not well studied. A recent single arm retrospective analysis on rectal cancer patients under 40 years of age has advocated that $87 \%$ of cancers are located at lower rectum, and two third of those necessitate an abdominoperineal resection (13). Current study has shown that tumors in younger patients are closer to dentate line, and consequently more often received an abdominoperineal resection than those over the age of 50 years. In our opinion, this may be a significant feature of rectal cancer at younger ages that has not been well analyzed in the literature, and has an impact on daily practice.

The primary outcome measure in the current study is survival. There is conflicting information about survival in the literature. Several institutional and nationwide studies have revealed no statistically significant difference in survival between young and elderly patients. Although may be biased due to the limited number of patients, at least two retrospective single institutional analyses have shown that survival is not impaired in young patients despite aggressive histological features of tumors in these cases $(6,9)$. In contrast, another study from University of Erlangen (7) has revealed statistically significantly worse overall and cancer-related survival rates in non-metastatic rectal cancer patients under the age of 50 years than in those over the age of 50 years; however, this information may be criticized to include stage four cancer cases. This particular issue is also investigated with SEER data twice. The first study in 2004 has analyzed 466 and 11,312 cases between the ages of 20 and 40 years, and between the ages of 60 and 80 years, respectively, and revealed similar overall and stage-specific 5-year survival rates (5). In contrast, a recent analysis in 2015, comparing 1274 and 37,077 cases between the ages of 20 and 39 years and over the age of 40 years, respectively, underlines a significantly shorter median survival in young cases (28 vs 31 months) (8). This study may be biased since the tumors in young cases are associated with advanced stages and worse histological features. Current study is significantly related to its case-match design considering similar stages in the groups. Although it may be criticized because of the limited number of patients particularly in the study group, no statistical difference has been revealed between the groups. Kaplan-Meier figure has shown a decrease in older patients after the $5^{\text {th }}$ year of follow-up. In our opinion, this finding is probably not related to the cancer recurrence, but the higher age in the $>50$ group. Thus, as the current information is supporting the same information, we believe that survival is similar in rectal cancer patients below the age of 40 years and over the age of 50 years, when similar tumor stages are analyzed.

Current study has some limitations. The retrospective design of the study and small number of patients are the paramount limitations. The lack of a power analysis is making some results questionable including operation technique, degree of differentiation and survival; where the statistical analysis is borderline significant or borderline not significant. Another important limitation of the current study is the lack of diseasefree survival analysis, which would probably rule out the impact of age difference between the groups. Besides, in our opinion, the case-match design of the study considering similar stages and homogeneity of the groups still make the current information valuable.

\section{Conclusion}

Current study analyzes the perioperative measures and survival of rectal cancer patients younger than 40 years and older than 50 years, and reveals similar results. Because of the limitations in the study, and conflicting information in the literature, further investigations are needed.

\section{Ethics}

Ethics Committee Approval: The study was approved by İstanbul Medipol University Ethics Committee (10840098-604.01.01-E21586).

Informed Consent: There were no direct interactions with subjects and knowledge gained would not impact subject's clinical care, informed consent were not obtained.

Peer-review: Externally and internally peer-reviewed.

Authorship Contributions: Concept - 0.C.; Design - M.0.; Data Collection or Processing - O.C.; Analysis or Interpretation - M.O.; Literature Search - O.C., M.O; Writing: O.C.

Conflict of Interest: The authors declare that they have no conflicts of interest.

Financial Disclosure: The authors declared that this study received no financial support. 


\section{References}

1. P, Whitley A, Blaha M, Hoch J. Colorectal cancer in patients under the age of 40 years: experience from a tertiary care center in the Czech Republic. Acta Chir Belg 2017; 117: 356-62.

2. Segev L, Kalady MF, Church JM. Left-Sided Dominance of Early-Onset Colorectal Cancers: A Rationale for Screening Flexible Sigmoidoscopy in the Young. Dis Colon Rectum 2018;61: 897-902.

3. Siegel R, Desantis C, Jemal A. Colorectal cancer statistics, 2014. CA Cancer J Clin 2014; 64: 104-117.

4. Siegel RL, Jemal A, Ward EM. Increase in incidence of colorectal cancer among young men and women in the United States. Cancer Epidemiol Biomarkers Prev 2009; 18: 1695-1698

5. O'Connell JB, Maggard MA, Liu JH, Etzioni DA, Ko CY. Are survival rates different for young and older patients with rectal cancer? Dis Colon Rectum 2004; 47: 2064-9.

6. Alici S, Aykan NF, Sakar B, Bulutlar G, Kaytan E, Topuz E. Colorectal cancer in young patients: characteristics and outcome. Tohoku J Exp Med 2003; 199: 85-93.

7. Schellerer VS, Merkel S, Schumann SC, Schlabrakowski A, Förtsch T, Schildberg C, et al. Despite aggressive histopathology survival is not impaired in young patients with colorectal cancer : CRC in patients under 50 years of age. Int J Colorectal Dis 2012; 27: 71-9.

8. Tawadros PS, Paquette IM, Hanly AM, Mellgren AF, Rothenberger DA, Madoff RD. Adenocarcinoma of the rectum in patients under age 40 is increasing: impact of signet-ring cell histology. Dis Colon Rectum 2015; 58: 474-8.

9. Lino-Silva LS, Salcedo-Hernández RA, Ruiz-García EB, León-Takahashi AM, García-Pérez L. Outcome of young patients with rectal adenocarcinoma. J Gastrointest Oncol 2017; 8: 96-101.

10. You YN1, Dozois EJ, Boardman LA, Aakre J, Huebner M, Larson DW.Youngonset rectal cancer: presentation, pattern of care and long-term oncologic outcomes compared to a matched older-onset cohort. Ann Surg Oncol 2011; 18: $2469-76$

11. O'Connell JB, Maggard MA, Livingston EH, Yo CK. Colorectal cancer in the young. Am J Surg 2004; 187: 343-8.

12. Meyer JE, Narang T, Schnoll-Sussman FH, Pochapin MB, Christos PJ, Sherr DL. Increasing incidence of rectal cancer in patients aged younger than 40 years: an analysis of the surveillance, epidemiology, and end results database. Cancer 2010; 116: 4354-9.

13. Haroon N, Khan S, Alvi R. Rectal carcinoma under 40 years of age: seven-year post-treatment follow-up at a tertiary care hospital in Pakistan. J Pak Med Assoc 2013; 63: 1460-3. 